\title{
A Study of Locus of Control and Achievement Motivation among students of Jalgaon Dist.
}

\author{
Dr. C. P. Labhane ${ }^{1}$, Prof. H. R. Nikam², Mr. Pravin. A. Baviskar ${ }^{3 *}$
}

\section{ABSTRACT}

The present study aims to determine the status of locus of control and achievement motivation among school going students of Jalgaon dist. The sample consists of 120 subjects 60 male and 60 female school going students. Total sample selected into the rural and urban area from Jalgaon Dist. The subjects selected in the sample were in the age range of 14-18 who are living in urban and rural areas. Standardized psychological test was used for data collection that is locus of control and achievement motivation test. After doing this scoring data was treated as mean, SD, t.

\section{Keywords: Locus of Control, Area, Achievement Motivation and School Students}

Indian education system is plying the important role of students over all development. Education is the most important for any person. Today's education system is developing of every field of education. Every student has centralized of education system because education system doesn't run for students. Parents are playing important role and supporting their children academic achievement. Many family environments, economic status, family culture and parents' involvement will be affect students achievements. Generally, many educators agreed that motivation is one of the basic factors of educational achievement. In other words, motivation is the basic factor in educational achievement. (Shamloo, 1970). Achievement motivation is a multilateral tendency to evaluate one's actions according to the best criteria, effort for success in actions and encountering enjoyment which is associated with success in actions. Studies in this field revealed that individuals are very different from each other regarding their needs. Some individuals have high level of motivation and try hard to gain success in their work by competing others .Others have no motivation for achievement and success and they do not risk to gain success because of the fear of failure. People attribute the course or control of events either to themselves or to the external environment. Those who ascribe control of event to themselves are said to have an internal locus of control and are referred to as "internal". People who attribute control to outside force are said to have an external locus of control and are referred to as "externals". Locus of control is a cognitive style or personality trait characteristics by a

\footnotetext{
${ }^{1}$ HOD, Dept of Psychology, M.J.College, Jalgaon

${ }^{2}$ HOD, Dept of Psychology, Nanasaheb Y.N.C.College, Chalisgaon

${ }^{3}$ Research Fellow, Dept of Psychology, S.S.M.M.College, Pachora., Dist- Jalgaon (MS) India *Corresponding Author

(C) 2015 I C Labhane, H Nikam, P Baviskar; licensee IJIP. This is an Open Access Research distributed under the terms of the Creative Commons Attribution License (http://creativecommons.org/licenses/by/2.0), which permits unrestricted use, distribution, and reproduction in any Medium, provided the original work is properly cited.
} 


\section{A Study of Locus of Control and Achievement Motivation among students of Jalgaon Dist.}

generalized expectancy about the relationship between behavior and reinforcement in the form of reward and punishment. Many people are internal locus of control tend to expect reinforcement to be the consequence of their own efforts of struggle. Another people are external locus of control expect them to be the consequence of luck, fate or the action of powerful others.

\section{REVIEW OF THE STUDY}

Numerous studies have shown that being extremely extrovert in the form of learned helplessness and neglecting efforts and responsibilities as well as one who is extremely introvert are abnormal because of challenges to reality (Klein \& Keller, 1996). On the contrary, those with an external locus of control feel more frustration, anxiety and stress (Ghasemi, 1375). Results show that the locus of control is a strong, significant predicator of health and life satisfaction (Kelly, 2000). In another research, a relationship between locus of control and academic achievement has been observed; others have reported a negative relationship between external locus of control and academic achievement (Wood, Saylor, \& Cohen, 2009). McClelland et al. (1953).

Our locus of control will have a high influence on our behaviors. Individuals with external locus of control believe that their behaviors or their skills make no difference in getting reinforcement and they do not value their efforts. These people have less belief that they can control their lives in the present or future .Internal- oriented individuals believe that they have infinite control on their life and act according to that. These individuals tend to get higher ranking in the school and get higher grades in testing educational motivation. Also, they are determined to try more, recognize better, read more and have more efficiency in getting information (Scholts, 1987).

The students with internal locus of control showed a better performance, while there was no clear and obvious opinion. Hummer explained that individual differences influence the locus of control of the responses, because individuals with internal locus of control tend to resist to the effects and external infusions. Whereas, individuals with external locus of control become happy from the influence of external infusions. These findings imply that instructors must link their nature and frequency of ideas regarding individual characteristics of the student (Ghazanfari, 1992).

The present study was planned and performed to study the locus of control and achievement motivation among high school students of Jalgaon Dist (MS).

\section{OBJECTIVES OF THE STUDY}

- To find out the difference in locus of control of urban and rural area students.

- To find out the difference in locus of control of male and female students

- To find out the difference in achievement motivation of urban and rural area students.

- To find out the difference in achievement motivation of male and female students 


\section{HYPOTHESIS OF THE STUDY}

- There is no significant difference in external locus of control between the rural and urban area students.

- There is no significant difference in internal locus of control between the rural and urban area students.

- There is no significant difference in achievement motivation between the rural and urban area students.

- There is no significant difference in external locus of control between the male and female students.

- There is no significant difference in internal locus of control between the male and female students.

- There is no significant difference in achievement motivation between the male and female students.

\section{Variables}

- Independent variable -
A) Gender - 1) Male
2) Female
B) Area -1) Urban
2) Rural

- Dependent variable -
A) Locus of control
B) Achievement of motivation

\section{METHODOLOGY}

\section{Sample}

The sample of the study consists of 120 students (60 male and 60 female) Sample of the study was selected by simple random sampling from the school going students of jalgaon Dist. Their age range was 14-18 years. Thus, the male and female student's ratio was 1:1.

\section{Tools}

Locus of control - test was constructed and standardized by Dr. Jullian Rotter.

Achievement of motivation - test was constructed and standardized by Dr. Deo Mhan.

\section{Research Design}

Since, there were two independent variables and each variable was classified at two levels. A 2x2 factorial design was used.

\section{Statistical Treatment of Data}

First, the data were treated by means, SD and t. SPSS software (Version 17.0) was used for data analysis. 


\section{RESULT AND DISCUSSION}

In this part investigator has explained the result related to statistical analysis and hypothesis.

HY-01- There is no significant difference in external locus of control between the rural and urban area students.

Table no- 01 - Area wise comparison on external locus of control

\begin{tabular}{|c|c|c|c|c|c|c|}
\hline \multirow{2}{*}{$\begin{array}{c}\text { External } \\
\text { Locus of } \\
\text { control }\end{array}$} & Area & $\mathbf{N}$ & $\mathbf{M}$ & SD & $\mathbf{t}$ & Sig. Level \\
\cline { 2 - 7 } & Urban & 60 & 6.58 & 1.44 & 2.23 & Sig. \\
\cline { 2 - 7 } & Rural & 60 & 7.10 & 1.06 & & 0.05 \\
\hline
\end{tabular}

$P$ at $0-05=1.98,0.01=2.61$

Table no 01 shows the level of external locus of control among urban and rural area students. The researcher found that the mean value in external locus of control of urban area students was 6.58 and SD is 1.44. Similarly the mean value in external locus of control of rural area students was 7.10 and SD is 1.06. The calculate " $\mathrm{t}$ " value is 2.23. It is significant at 0.05 levels. It is indicates that there is significant difference in external locus of control between the urban and rural area students. That's why above hypothesis is rejected.

HY-02- There is no significant difference in internal locus of control between the rural and urban area students.

Table no- 02 - Area wise comparison on internal locus of control

\begin{tabular}{|c|c|c|c|c|c|c|}
\hline \multirow{2}{*}{$\begin{array}{c}\text { Internal } \\
\text { Locus of } \\
\text { control }\end{array}$} & Area & $\mathbf{N}$ & $\mathbf{M}$ & $\mathbf{S D}$ & $\mathbf{t}$ & Sig. Level \\
\cline { 2 - 5 } & Urban & 60 & 5.53 & 0.98 & 6.76 & Sig. 0.01 \\
\cline { 2 - 5 } & Rural & 60 & 6.88 & 1.99 & & \\
\hline
\end{tabular}

$P$ at $0-05=1.98,0.01=2.61$

Table no 02 shows the level of internal locus of control among urban and rural area students. The researcher found that the mean value in internal locus of control of urban area students was 5.53 and SD is 0.98. Similarly the mean value in external locus of control of rural area students was 6.88 and SD is 1.99. The calculate "t" value is 6.76. It is significant at 0.01 levels. It is indicates that there is significant difference in internal locus of control between the urban and rural area students. That's why above hypothesis is rejected.

HY-03- There is no significant difference in achievement motivation between the rural and urban area students.

Table no- 03 - Area wise comparison on achievement of motivation

\begin{tabular}{|l|c|c|c|c|c|c|}
\hline \multirow{2}{*}{$\begin{array}{l}\text { Achievement } \\
\text { motivation }\end{array}$} & Area & N & M & SD & t & Sig. Level \\
\cline { 2 - 5 } & Urban & 60 & 39.20 & 3.44 & 3.49 & Sig. 0.01 \\
\cline { 2 - 5 } & Rural & 60 & 36.68 & 4.39 & & \\
\hline
\end{tabular}

$P$ at $0-05=1.98,0.01=2.61$

Table no 03 shows the level of achievement motivation among urban and rural area students. The researcher found that the mean value in achievement motivation of urban area students was 39.20 and SD is 3.44. Similarly the mean value in achievement motivation of rural area students 
A Study of Locus of Control and Achievement Motivation among students of Jalgaon Dist.

was 36.68 and SD is 4.39. The calculate " $t$ " value is 3.49. It is significant at 0.01 levels. It is indicates that there is significant difference in achievement motivation between the urban and rural area students. That's why above hypothesis is rejected.

HY-04 -There is no significant difference in external locus of control between the male and female students.

Table no- 04 - Gender wise comparison on external locus of control

\begin{tabular}{|l|c|c|c|c|c|c|}
\hline \multirow{2}{*}{$\begin{array}{l}\text { External } \\
\text { locus of } \\
\text { control }\end{array}$} & Gender & $\mathbf{N}$ & $\mathbf{M}$ & SD & t & Sig. Level \\
\cline { 2 - 7 } & Male & 60 & 6.68 & 1.52 & 3.50 & Sig. 0.05 \\
\cline { 2 - 7 } & Female & 60 & 7.53 & 1.09 & & \\
\hline
\end{tabular}

$P$ at $0-05=1.98,0.01=2.61$

Table no 04 shows the level of external locus of control among male and female students. The researcher found that the mean value in external locus of control of male students was 6.68 and SD is 1.52. Similarly the mean value in external locus of control of female students was 7.53 and $\mathrm{SD}$ is 1.09 . The calculate "t" value is 3.50 . It is significant at 0.01 levels. It is indicates that there is significant difference in external locus of control between the male and female students. That's why above hypothesis is rejected.

HY-05 -There is no significant difference in internal locus of control between the male and female students.

Table no- 05 - Gender wise comparison on internal locus of control

\begin{tabular}{|l|c|c|c|c|c|c|}
\hline \multirow{2}{*}{$\begin{array}{l}\text { Internal locus } \\
\text { of control }\end{array}$} & Gender & $\mathbf{N}$ & $\mathbf{M}$ & $\mathbf{S D}$ & $\mathbf{t}$ & Sig. Level \\
\cline { 2 - 7 } & Male & 60 & 5.53 & 0.98 & 0.20 & NS \\
\cline { 2 - 5 } & Female & 60 & 5.56 & 0.81 & & \\
\hline
\end{tabular}

$P$ at $0-05=1.98,0.01=2.61$

Table no 05 shows the level of internal locus of control among male and female students. The researcher found that the mean value in internal locus of control of male students was 5.53 and SD is 0.98 . Similarly the mean value in internal locus of control of female students was 5.56 and $\mathrm{SD}$ is 0.81 . The calculate " $\mathrm{t}$ " value is 0.20 . It is indicates that there is no significant difference in internal locus of control between the male and female students. That's why above hypothesis is accepted.

HY-06- There is no significant difference in achievement motivation between the male and female students.

Table no- 06 - Gender wise comparison on achievement of motivation

\begin{tabular}{|l|c|c|c|c|c|c|}
\hline \multirow{2}{*}{$\begin{array}{l}\text { Achievement } \\
\text { motivation }\end{array}$} & Gender & $\mathbf{N}$ & $\mathbf{M}$ & SD & t & Sig. Level \\
\cline { 2 - 6 } & Male & 60 & 37.66 & 4.11 & 2.36 & \begin{tabular}{c} 
Sig. \\
\cline { 2 - 5 }
\end{tabular} \\
\cline { 2 - 7 } & Female & 60 & 35.61 & 5.31 & & 0.05 \\
\hline
\end{tabular}

$P$ at $0-05=1.98,0.01=2.61$

Table no 06 shows the level of achievement motivation among male and female students. The researcher found that the mean value in achievement motivation of male students was 37.66 and 
SD is 4.11. Similarly the mean value in achievement motivation of female students was 35.61 and SD is 5.31. The calculate " $\mathrm{t}$ " value is 2.36. It is indicates that there is significant difference in achievement motivation between the male and female students. That's why above hypothesis is rejected.

\section{DISCUSSIONS}

The aim of the present study was to find out the difference in locus of control and achievement motivation of secondary school going students.

First hypothesis result obtained after analysis it data are show table no-01 reveals that there would be significant difference was found between urban and rural area students with reference to their external locus of control. This significant "t" value (2.23) indicates that area significantly affects the external locus of control. This reveals the fact that rural area students have high level of external locus of control than urban area students. Rural area students have belonged to spiritual environment because our locus of control will have a high influence on our behaviors. Individuals with external locus of control believe that their behaviors or their skills make no difference in getting reinforcement and they do not value their efforts. These people have less belief that they can control their lives in the present or future. That is why the above finding can be supported by the conclusion of the studies carried out by Scholts, 1987.

Second hypothesis result obtained after analysis it data are show table no-02 reveals that there would be significant difference was found between urban and rural area students with reference to their internal locus of control. This significant "t" value (6.76) indicates that area significantly affects the internal locus of control. This reveals the fact that rural area students have very high level of internal locus of control than urban area students. The students with internal locus of control showed a better performance, while there was no clear and obvious opinion. Hummer explained that individual differences influence the locus of control of the responses, because individuals with internal locus of control tend to resist to the effects and external infusions. That is why the above finding can be supported by the conclusion of the studies carried out by Hummer 1992.

Third hypothesis result obtained after analysis it data are show table no-03 reveals that there would be significant difference was found between urban and rural area students with reference to their achievement motivation. This significant "t" value (3.49) indicates that area significantly affects the achievement motivation. This reveals the fact that urban area students have better level of achievement motivation than rural area students. Urban area has more develop than rural area. Urban area student's families environments are a very motivational then family member have an economically and emotionally supported for them. Study materials are easily available of urban area students. 


\section{A Study of Locus of Control and Achievement Motivation among students of Jalgaon Dist.}

Fourth hypothesis result obtained after analysis it data are show table no-04 reveals that there would be significant difference was found between male and female students with reference to their external locus of control. This significant "t" value (3.50) indicates that area significantly affects the external locus of control. This reveals the fact that female students have high level of external locus of control than male students. Female students are more religious spiritual than male students. Spirituality and religious have played the important role of human development. On the contrary, those with an external locus of control feel more frustration, anxiety and stress (Ghasemi, 1375). Results show that the locus of control is a strong, significant predicator of health and life satisfaction. That is why the above finding can be supported by the conclusion of the studies carried out by Kelly, 2000.

Hypothesis no 05 Result obtained after analysis it data are show table no -05 reveals that there is no significant difference was found between male and female students with reference to their internal locus of control. That's why above hypothesis is accepted.

Hypothesis no 06 result obtained after analysis it data are show table no-06 reveals that there would be significant difference was found between male and female students with reference to their achievement motivation. This significant " $t$ " value (2.36) indicates that area significantly affects the achievement motivation. This reveals the fact that male students have high level of achievement motivation than female students. Achievement motivation is caused from the accumulation dreams of the child. When a child faces a new condition of success like a scientific riddle, he/she has no expectation of his/ her ability to solve that. Achievement motivation is caused from the accumulation dreams of the child. When a child faces a new condition of success like a scientific riddle, he/she has no expectation of his/ her ability to solve that. That is why the above finding can be supported by the conclusion of the studies carried out by Abdoli, 1987

\section{CONCLUSION}

- There is significant difference in external locus of control between the rural and urban area students.

- There is significant difference in internal locus of control between the rural and urban area students.

- There is significant difference in achievement motivation between the rural and urban area students.

- There is significant difference in external locus of control between the male and female students.

- There is no significant difference in internal locus of control between the male and female students. This hypothesis is accepted.

- There is significant difference in achievement motivation between the male and female students. 


\section{REFERENCES}

Ahmad.A.Kader, (2014) Locus of Control, Student Motivation, and Achievement in Principles of Microeconomics,Vol. 4, No. 9; American International Journal of Contemporary Research.

Ali Akbar, Mitra Yousefzadeh(2011) Survey on relationship of achievement motivation, locus of control and academic achievement in high school students of Bandar Abbas (Iran), Procedia - Social and Behavioral Sciences 30 (2011) 866 - 870.

Bhupinder Singh,Onkar Singh,Baljinder Singh (2012) A Comparative Study of Achievement Motivation and Locus of Control of University Level Team and Individual Sports, Vol. 2, Issue 2, International Journal of Education and applied research.

Coakes, Steed, Dzidic (2010) SPSS version 13.0 for windows, Wiley student edition, Delhi. Eysenck, H. J. (1947) Dimensions of Personality. London: Routledge and Kegan Paul Ltd Horton.P.B. (1982) Sociology, $4^{\text {th }}$ ed, International student edition, McGraw Hill Publication. Kalantarkousheh, Mohagheghi (2013)Surveying the Relationship between Locus of Control and Academic Achievement among Students at Allameh Tabataba'I University Volume 3, Issue 12, International Journal of Physical and Social Sciences

Kerlinger .F.N. (2007) Foundation of Behavioral Research, $2^{\text {nd }}$ edDelhi, Surjeet Publications Morgan .C.T. (2001) Introduction to Psychology, Tata McGraw Hill Publications. 